\title{
What Happens Next?
}

Omari 'Motion' Carter, The Motion Dance Collective

Keywords: teaching, screendance, spoken word, hip-hop, dance film, rap, Covid-19, zoom, online, The Motion Dance Collective, Mitchell Rose, Omari Carter, What Happens Next

a-Welcome to the class, welcome to the class.

Make sure you've got a webcam and your internet is fast. We've got time for a warm up so I'm sharing through the sound. So turn your speakers up and mute your microphones now. Look...

My name's Omari 'Motion' Carter that's for starters.

Screendance practitioner with the Master's, lecturer at universities with dancers, and produce dance-film with The Motion Dance Collective objectives, with hip-hop's perspective. I be "ebonically linguistic"1 with the rhetoric while academically legit.

So listen carefully and check out all the references, there's knowledge in the words I spit.

I want to talk about the problems

I've been having teaching.

How pandemic present has affected all my lessons. Bridging the gap with a rap is my rhyming's reason.

So take a seat, sip a tea, and let's start the session from the bottom, to implement a base.

Beginning with the novice in the screendance space...

With limited time to teach them what they should know, do we need shutter speed, aperture, ISO? I asked Mitchell Rose and he said no, reorienting their thinking is the way to go. ${ }^{2}$

Oh! So have I been teaching all wrong?

Was I implementing camera theory all too strong?

Has this digital detachment thrown my practice in a realm where my teaching is now limited to lecturing film?

I know my goal is to make film methods tangible and for dancers this process is much more manageable. ${ }^{3}$ However, I could not imagine at all, that I'd have to shift initially to teaching verbal.

When we all know the best workshops 
either start with walking around the space, laying on floors or sitting in circles. Uh!

a-Welcome to the class that takes place in your room. I'm sorry that your late, you should have downloaded Zoom. This is being recorded though for you to watch back and if you want to check the videos they're posted in the chat.

I don't want to teach online... Is that a crime?

Face-to-face knowledge was working out just fine. I had my notes, the projector, a huge dance space, and a stopwatch set to keep time.

Of course the necessity is undisputed, but engaging creative minds while their muted is not what I computed.

I also wonder if it's good for my health, since the first sign of madness is talking to yourself. Listen...

It's also impossible to know what I lack, cause as an hourly paid lecturer I don't get the feedback.

Most organisations assuming that screendance education is as easy as a screen and an educator.

Re-writing modules with the phobia of trial and error; Blackboard/Moodle network architecture; Face-to-face, live-stream, pre-recorded lecture; Adequate schooling? A matter of conjecture.
So I reached out to dance-filmmakers under separate names, to provide mutual support and thoughtful exchange.

But these came mostly in the form of empathy texts, as we keep our altered exercises close to our chests. Couldn't say I aim to blame, we all need a paycheck. A place to share experiences is what we need next.

That's what we need next...

So what happens next?

So here I am:

Editing dances, while teaching classes and being asked 'Sir? How do we pass this?' Well here's the truth kids. I got my Masters by making my interests worth more than the marks were.

Being authentically you is the answer, regardless of the modes in which you're taught to be dancers. You mould the mode to move your moving images.

Flip the

script to rip apart your scrimmages...

You should be having Conversations like you're Malaolu; ${ }^{4}$ Curating other artists like my man Mr Opoku-Addiae. ${ }^{5}$ 
Solidifying process? No stress;

Common Dance like Lee, ${ }^{6}$

direct like Morg \& Jess, ${ }^{7}$

hyper-match like Mitch, ${ }^{8}$

journal like Kappenberg, ${ }^{9}$

location scout like Millar, ${ }^{10}$

write like Rosenberg. ${ }^{11}$

As hard as it may seem

to work in these extremes

and to explore the practice of

screendance practically.

Disseminating knowledge

through these digital means

has, to my surprise, come quite naturally.

I'm not sure if that's because I'm under 33 or when it comes to analogue,

I know it ends with a ' $g$ '?

a-Welcome to the class

I think that you will find, we were meant to be face-to-face

but Boris changed his mind. ${ }^{12}$

I've made a whole new schedule and I hope it's not too strange.

And just like the whole world right now, it is subject to change.

Asking podiums at symposiums

in particular,

How do we mark the language in the screendance curricula?

In your digestion of that

rhetorical question

let me recommend

a couple of suggestions.

Number 1: Let's have fun;

Lighting simple - lamp, torch, sun;

Flick on a soundtrack

that's copyright free;

Explore every axis: $X-Y-Z$.

Suggestion 2: we already know what to do: Netflix, Facebook, Vimeo, YouTube -

So much information coming at us

in a loop;

So much screen time

that we professionally view.

So what happens when years of viewing is put to use?

Knowledge comes from each individual

frame you peruse.

The art is showing us

how it reacts to the times.

I can only guide its processes

a limited amount.

But if I was to give this period a title, I wonder if the splitscreen era counts?

Let's advocate developments of more embodied learning.

Through exercises utilised in our creative teaching.

Physically advancing

an approach to the screendancing that affects the many ways in which we are currently filming.

We owe it to ourselves, to be proud of our process.

Hold our heads high

as we hope for a time that is zoom-less.

Even if at times we feel clueless.

Know that our practice isn't rootless.

Relish in the NOWNESS ${ }^{13}$

and the newness.

Know that you can do this.

Experience never renders you useless, so remain ruthless.

Be an optimistic opportunist.

The best single way to conclude is...

a-Welcome to the class

I think it's time to end

I thank you all for coming

and I hope you re-attend. 
I think l've said my piece (a rant it may have seemed to be).
I wish you all adieu

and hope your paths stay Covid-free.

\title{
Listen to "What Happens Next?" on Soundcloud:
}

https://soundcloud.com/omari-carter/what-happens-next-1/s-4Gv7bv4Qlz8

\author{
Audio Credits
}

Original Composition and Performance by Omari 'Motion' Carter

Sound Engineering and Consultancy by Stacy Carter

\section{Biography}

Omari 'Motion' Carter is a screendance practitioner and lecturer based in London and, for the past decade, has been directing, choreographing, editing and performing for music videos, film, television and theatre. A first-class BA(Hons) degree in Performing Arts at London Metropolitan University led Omari to perform for 7 years in the West End and international touring productions of 'Stomp!' During this time, Omari choreographed, directed, performed and produced a varied reel of dance on film work with award winning Screendance production company, The Motion Dance Collective, of which he founded in 2011. His practice and research centre around hip-hop dance culture, body percussion, urbanity, and dance-film, with the aim of bridging the gap between the movers, makers and thinkers within the genre. Omari is associate lecturer in screendance at London Contemporary Dance School (LCDS), University of East London and Lincoln University and a graduate, with distinction, of the world's first MA in Screendance at LCDS. Omari's short dance-narratives have screened both in the UK and internationally at over 50 film and dance-film festivals, as he continues to push the critical awareness of narrative dance-film practice, through workshops, talks, podcasts, curations, screenings and commissions within the UK.

Email: info@motiondancecollective.com

Website: www.motiondancecollective.com 
Notes

${ }^{1}$ Q-Tip, "Start it Up" by A Tribe Called Quest.

${ }^{2}$ Filmmaker Mitchell Rose, speaking with The Motion Dance Collective in screendance podcast, The MDC Talks (July 19, 2020). This episode was unreleased at time of publication.

${ }^{3}$ Ellen Maynard as cited in Bench, "Screendance: Learning, Teaching, Living," 191.

${ }^{4}$ Lanre Malaolu, "The Conversation."

${ }^{5}$ Freddie Opoku-Addaie, SystemsLAB.

${ }^{6}$ Rosemary Lee, "Common Dance."

${ }^{7}$ Jessica Wright \& Morgan Runacre-Temple, https://www.jessandmorgs.com/

${ }^{8}$ Mitchell Rose, "Crowd-Sourced Filmmaking."

${ }^{9}$ Claudia Kappenberg, http://www.ckappenberg.info/

${ }^{10}$ Marlene Millar, https://www.marlenemillar.com/

${ }^{11}$ Douglas Rosenberg, Screendance.

12 "Boris Johnson has announced all primary and secondary schools will be shut for the whole of January amid ongoing backlash from teaching unions." 4 Jan. 2021. https://www.express.co.uk/news/uk/1379534/School-closures-live-update-UK-latestterm-dates-in-my-area-Covid-lockdown-rules

${ }^{13}$ NOWNESS. https://www.nowness.com/topic/dance

\section{References}

Opoku-Addaie, Freddie. https://freddieopoku-addaie.com/

Kappenberg, Claudia. http://www.ckappenberg.info/

Lee, Rosemary. Chor. "Common Dance." 2009. https://www.artsadmin.co.uk/ project/common-dance/

Maynard, Ellen as cited in Harmony Bench. "Screendance: Learning, Teaching, Living." The International Journal of Screendance 6 (2016). https://doi.org/10.18061/ijsd.v6i0.5232 
Millar, Millar. "Migration Dance Film Project." Series ongoing. https://www.marlenemillar.com/\#/mdfp/

NOWNESS. https://www.nowness.com/topic/dance

Q-Tip (Lyricist) as performed with A Tribe Called Quest [Rap Group]. Start it Up. Universal Music Publishing Group, Warner Chappell Music, Inc. New York. 1998.

Rose, Mitchell. "Crowd-Sourced Filmmaking: Despair is Your Friend." The International Journal of Screendance. 5 (2015). https://doi.org/10.18061/ijsd.v5i0.4608

---. In conversation with Omari Carter, Anna Clifford, and James Williams of The Motion Dance Collective on The MDC Talks. Podcast, unreleased.

Rosenberg, Douglas. Screendance: Inscribing the Ephemeral Image. New York: Oxford University Press, 2012.

"The Conversation" Dir. and chor. Lanre Malaolu. 2020. https://www.lanremalaolu.com/currentprojects

Wright, Jessica and Morgan Runacre-Temple. Jess \& Morgs. https://www.jessandmorgs.com/ 